\title{
Assessing the Buyer Trust and Satisfaction Factors in the E-Marketplace
}

\section{Sfenrianto Sfenrianto ${ }^{1}$, Tendi Wijaya ${ }^{2}$, and Gunawan Wang ${ }^{3}$}

${ }^{1}$ Bina Nusantara University, Information Systems Management Department, Jakarta, Indonesia, sfenrianto@binus.edu

${ }^{2}$ Bina Nusantara University, Information Systems Management Department, Jakarta, Indonesia, tendi.wijaya@binus.ac.id

${ }^{3}$ Bina Nusantara University, Information Systems Management Department, Jakarta, Indonesia, gwang@binus.edu

Received 5 April 2017; received in revised form 31 August 2017; accepted 19 October 2017

\begin{abstract}
Indonesian online sales have received remarkable growth with as high as $20 \%$ consistently every year. In 2016, there were estimated more than 180 million internet users and have reached $40 \%$ of 250 million total inhabitants. Based on the surveys, there are four most popular online vendors in Indonesia, such as: Lazada, Tokopedia, OnLine eXchange and Bukalapak, with strong customer bases. Due to its tremendous growth, however, there is still very few studies can be found to understand the characteristics of emarketplace in Indonesia. For this reason, the article examines those most popular online vendors in Jakarta area, where the most buyers tend to have more experiences in conducting online purchases. The article utilizes the revised TAM as a valuable method to assess the important factors of online purchases such as: buyer and satisfaction factors, that comprised of: buyer perceived risk, seller's expertise and reputation, and convenience of buying. The findings are aimed to address the important factors that can be used to increase buyer satisfaction. The outcomes of the study are expected to provide valuable guidance for all e-sellers and buyers to understand Indonesian e-marketplace.
\end{abstract}

Keywords: E-marketplace, Indonesian e-marketplaces, Buyers, Trust, Satisfaction, RevisedTechnology Acceptance Model 


\section{Introduction}

Since the last decade, the growth of e-marketplace in Indonesia has received remarkable results. Emarketplace is defined as an online intermediary designed to establish buyer-seller relationships and to facilitate the transactions between them. It involves at trilateral relationships such as: buyers, sellers, and managed by an e-marketplace provider [5]. In 2016, there were estimated more than 180 million internet users with $20 \%$ growth consistently every year. It accounts around $40 \%$ of from more than 250 million inhabitants with strong middleclass economy [14]. This fact is making the third largest consumer base in the world and occupies the seventh largest economy rank. Other fact attracts major investors is the demography of major population are dominated by the youngsters with nearly $60 \%$ of them below 30 years of age [17].

Based on a survey that was conducted by Nusaresearch.com in 2015, there were most four popular emarketplace vendors in Indonesia, such as: Lazada (Site 1), Tokopedia (Site 2), OLX (Site 3), and bukalapak (Site 4). They have strong customer bases and developed fast-growing places. Their presents indicate very promising markets [39], [36], [40], as well as alarming risks associated with them [15]. For Indonesian e-sellers, emarketplaces are perceived as new battlefields that surround with a new paradigm of running the business [45], [42]. E-marketplaces provide huge market opportunities as well as the challenges [10] to survive with them. In order to survive, they are required to develop an appropriately sophisticated level of services [50] that might not be anticipated before, to serve their large buyers [12].

The trust and satisfaction issues have become the major concerns faced by all e-buyers as well as sellers [16]. Scholars have addressed the important roles in improving online purchasing behaviors [6], [7] such as: trust, risk, seller's expertise, convenience [56], seller's reputation, website usability and security [31]. Doong et.al. [16] in their studies confirmed that seller expertise such as: sales experience and attitude, price fairness, the satisfaction of buying process and trust are all useful approaches to enhance buyers' loyalty intention and loyalty [52] in the online e-marketplaces.

Although these factors are considered important, unfortunately, there is still a very few study can be found to measure these issues in Indonesian e-marketplaces. For this reason, the article examined the major emarketplaces provider such as: Lazada (Site 1), Tokopedia (Site 2), OLX (Site 3), and bukalapak (Site 4) with revised-TAM model. The revised-TAM model is selected due to its advantages in examining the buyer trust and satisfaction factors that highlighted the essential e-marketplace components from the perspectives of: buyer perceived risk, seller's expertise and reputation, and convenience of buying. The revised TAM model is effectively to be used in measuring buyer's perceives and link them to developing expected behaviors. The outcomes of the study are expected to provide valuable insights for all e-sellers and buyers to understand Indonesian emarketplaces.

\section{Research Design}

E-marketplace should be referred on the credibility based trust transferred from one source to another that facilitates collaborations and business interactions among buyers and sellers virtually [28]. Building credibility based trust to the buyers and sellers, however, it is not an easy task, since virtual media poses potential risks for both parties, especially dealing with low trust society [35], such in Indonesia. DBS insight in 2015 [8] stated that Indonesian e-marketplaces are still haunted with the major threat issues such as online shopping has a fraudulent image, unable to test the product, payment is not safe/convenient, higher price compared to ordinary price, product quality is unreliable, and unsatisfactory online sales support.

In e-marketplace, privacy and security [9] are the main features that are not only enhancing competitive advantages, but also increasing the level of trust [2]. Trust plays important roles in moderating the firm willingness to adopt e-sales and buyer participation [9], [48]. Trust takes a vital role in a wide spectrum of human interactions, among the cooperation, network relations and crisis management [10]. Buyer's trust in one component of the e-marketplace merchant may not only affect their trust in the other, however, also influence the way buyers make online purchases [24]. Based on these facts, assessing the perceived risk in e-marketplace is prerequisite measures to minimize the possibility loss between sellers and buyers in e-marketplaces [57]. Buyers concerned about a loss of privacy, misuses of personal information, and quality of product [9]. It can be understood due to the importance of trust a significant the impact of customers' trust [44]. Chang and Wong [5] examined the trust factors in e-procurement and participation of e-marketplace should consist of: ability (marketplace's competency, technical expertise, knowledge and capability to perform its role), friendliness, safety (fairness, integrity, responsibility and commitment), and predictability (sufficient knowledge and accurate information to make predictions and judgements). Literature studies show that good perceived risk management has a positive impact on the online trust [28], [30], [33], [44], [56]. Based on this study, we formulate the hypothesis as:

H1: Perceived risk assessment of online shopping has positive effects on buyer trust. 
Perceived of usefulness is one of the key factors of TAM (Technology Acceptance Model) that used in the article. TAM was introduced by Davis in 1986 [13] that is used to describe the behavior of users in the use of information technology. Perceived usefulness is defined as the degree to which a person believes that using a certain information technology will improve his or her performance [13]. Perceived usefulness in the article refers to subjective usability in terms of reaching buyers and sellers, enhancing operational efficiency, and improving the quality of buyer service to both buyers and sellers [18], [28], [47]. There are increasing trends of Indonesian buyers to shop online, and these trends become challenges for the sellers to improve their e-application usefulness. We formulate hypothesis as:

\section{H2: Perceived usefulness of online shopping has positive effects on buyer trust.}

Perceived ease of use is another key factor in TAM. Perceived ease is defined as the extent to which a person believes by using an information technology would be free from effort. Smith and Spiers [47] addressed the roles of perceived usefulness in e-marketplaces with creating behavior intention to use it, somewhere is quite strong. Along with perceived of usefulness, the perceived ease of use measures the easy and minimum effort of buyer roles in e-marketplace [28]. Perceived ease of use is an important issue to address due to large of buyers that are newly exposed to e-marketplaces.

\section{H3: Perceived ease of use of online shopping has positive effects on buyer trust.}

Reputation takes important roles in shaping the e-marketplace, especially dealing with pricing and promoting sales [27]. E-marketplace reputation reflects the overall evaluation, image, and the identification of an emarketplace [6]. Higher reputation is believed often represents higher profits [19].

\section{H4: Indonesian e-marketplaces reputation has positive effects on buyer trust.}

The seller's reputation reflects the confidence in the ability of sellers to provide high-quality services and the level of the confidence that attached to the information which provided by the seller before the transaction [9]. However, in under certain circumstances, a high-reputation seller might probably develop greater intention to cheat [25]. Promoting seller reputation is not an easy task for Indonesian sellers, due to new seller exposure to online transactions.

\section{H5: e-Seller's reputation has positive effects on buyer trust.}

Seller's expertise plays an important role in shaping and developing buyer confidence in predicting the quality of the products and the seller. With appropriate selling strategies, the seller can lead to higher selling prices and promote sales [20]. On the other hand, some buying strategies also can lead to lower prices [49]. Seller's expertise can affect the credibility of the seller and can help reduce uncertainty and increase the confidence [31]. Indonesian e-marketplaces are still new to all stakeholders, sellers need to develop their expertise's that enable them to maximize the benefits of e-marketplaces.

\section{H6: E-Seller's expertise has positive effects on buyer trust.}

Convenience refers to the extent to which a buyer feels that a website is easy to navigate [18]. The effective seller can be measured in the way they established interpersonal relationships with her buyers, in order to develop tolerance, commitment, preference, productivity, and efficiency [55], [53].

\section{H7: Convenience in online shopping has positive effects on buyer trust.}

Buyer satisfaction is another important factor in measuring the effectiveness of e-marketplaces. The determinants of customer satisfaction through online shopping are summarized as: convenience, web-site design, financial security, trust, assurance, reliability, information, merchandise variety, perceived ease of use and usefulness, entertainment, speed, response time and transaction capability [34]. It is said that the internet users may frequently visit the shopping sites, however, it does not automatically generate sales. Christer [10] supported this argument and addressed that institutional trust in an e-marketplace does not automatically influence interpersonal buyer-seller trust. Buyer satisfaction takes place when products and services meet the expectation of the buyers. It is very important for any seller in the marketplace enables to provide the website, with products and services to the certain extent, that enables to lead the buyers to be loyal and willing to make repetitive purchases [26]. Jiradilok et.al. [26] reported the good website quality system and tangibility have no influence on purchasing intention in buyer's decision even though the respondents were quite satisfied with these dimensions. Service quality dimensions are the important issues that need to be understood by any seller since they have important impacts on creating buyer satisfaction on online purchases [43].

With the similar trust hypotheses above, we formulate the hypotheses for buyer satisfaction as:

H8: Perceived usefulness of online shopping has positive effects on buyer satisfaction. 
H9: Perceived ease of use of online shopping has positive effects on buyer satisfaction.

H10: E-Seller's expertise has positive effects on buyer satisfaction.

H11: Convenience in online shopping has positive effects on buyer satisfaction.

H12: Trust in online shopping has positive effects on buyer satisfaction.

\section{Methodology}

The article examines the research model in Indonesian marketplace that comprised of trust and satisfaction components. In this section, research model, and data gathering method have been presented.

\subsection{Research Method}

This article examines the research model for examining trust and satisfaction factors in Indonesian e-marketplaces comprised of following variables and indicators (see Table 1).

Table 1: Research variables and its indicators

\begin{tabular}{|c|c|c|}
\hline Variables & Indicators & References \\
\hline \multirow{2}{*}{ Perceived Risk (H1) } & Privacy (PR1) & [28], [56], \\
\hline & Time risk and Product risk (PR2) & [2], [9], [35], [48] \\
\hline \multirow{3}{*}{ Perceived Usefulness $(\mathrm{H} 2) \&(\mathrm{H} 8)$} & Usefulness of content (PU1) & [9], [30], [56] \\
\hline & Effectiveness of shopping (PU2) & [9], [48] \\
\hline & Productivity (PU3) & [9] \\
\hline \multirow{3}{*}{$\begin{array}{l}\text { Perceived Ease of Use }(\mathrm{H} 3) \text { \& } \\
(\mathrm{H} 9)\end{array}$} & Ease features (PEOU1) & [53], [55], [56] \\
\hline & Ease navigation (PEOU2) & {$[55],[56]$} \\
\hline & Ease shopping (PEOU3) & {$[8],[30]$} \\
\hline \multirow{3}{*}{ E-marketplace Reputation (H4) } & Very famous (PEOU1) & \multirow{3}{*}{$\begin{array}{l}\text { [6], [9], [10], [19], [25], [27], } \\
{[28]}\end{array}$} \\
\hline & Recognition (PEOU2) & \\
\hline & Reputation/Image MR3 (PEOU3) & \\
\hline \multirow{3}{*}{ Seller's Reputation (H5) } & Other buyers' evaluation (SR1) & \multirow{3}{*}{ [7], [10], [20], [31], [49] } \\
\hline & Seller level (SR2) & \\
\hline & Seller's reputation (SR3) & \\
\hline \multirow{3}{*}{ Seller's Expertise $(\mathrm{H} 6)$ \& $(\mathrm{H} 10)$} & Seller's knowledge (SE1) & \multirow{3}{*}{$\begin{array}{l}\text { [7], [10], [20], [20], [31], [43], } \\
{[49]}\end{array}$} \\
\hline & Expertise to answer question (SE2) & \\
\hline & Description of product (SE3) & \\
\hline \multirow{2}{*}{ Convenience $(\mathrm{H} 7)$ \& $(\mathrm{H} 11)$} & Saving time (CONV1) & \multirow{2}{*}[18]{$,[53],[55]$} \\
\hline & Shopping every time (CONV2) & \\
\hline \multirow{3}{*}{ Trust } & Abiltity (TRS1) & \multirow{3}{*}[10]{,$[30]$} \\
\hline & Safety (TRS2) & \\
\hline & Predictability (TRS3) & \\
\hline \multirow{3}{*}{ Satisfaction } & Web-site design (STS1) & \multirow{3}{*}[26]{,$[34]$} \\
\hline & Entertainment (STS2) & \\
\hline & Response time (STS3) & \\
\hline
\end{tabular}

The proposed research model is illustrated in Figure 1. 


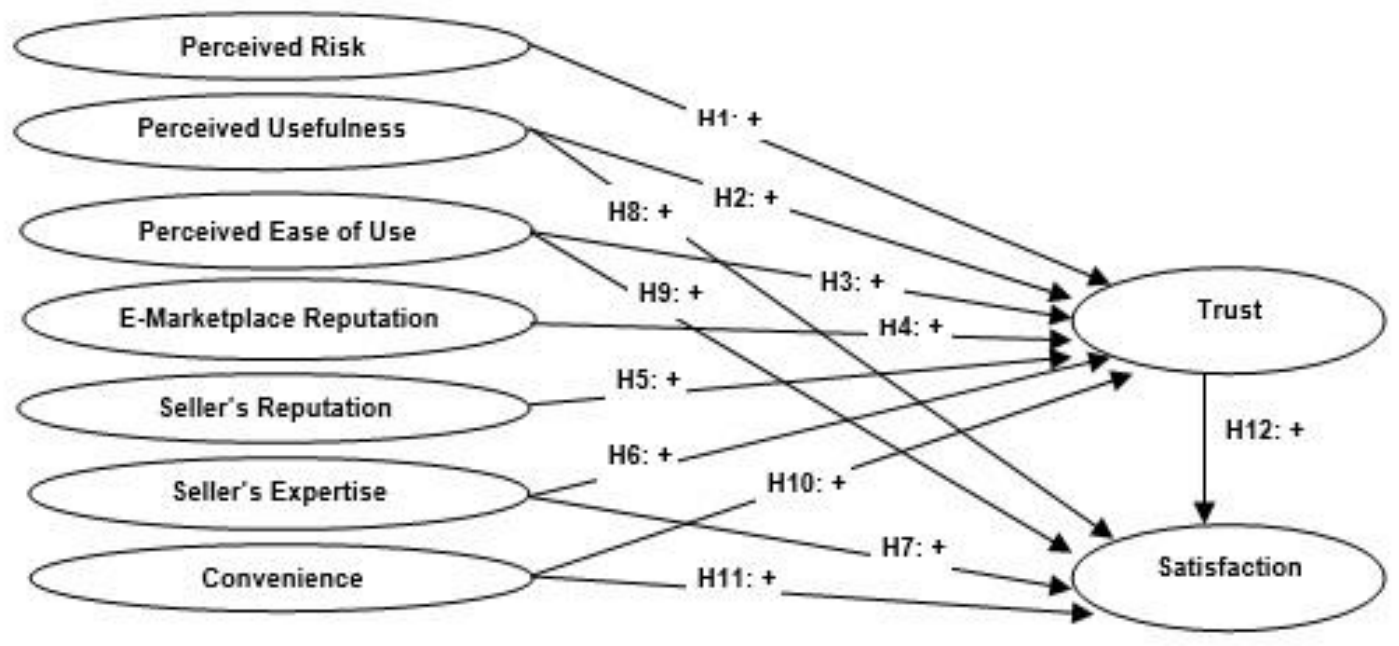

Figure 1: Research model trust and satisfaction in Indonesian e-marketplaces

\subsection{Data Gathering Method}

The study used questionnaire with a Likert scale of 5, and distributed to 2,000 respondents with convenience sampling method in Jakarta area during the period March-September 2016. The Jakarta area was selected due to a large number of online purchases were done by Jakarta buyers. The questionnaires were delivered through emails, forums, social media networks, and face-to-face with the respondents. The interview process to selected respondents also had been conducted to verify all questionnaires. Based on the questionnaires replied and checked, 547 questionnaires were valid for further analysis (See table 2 and 3 for the details).

Table 2: List of e-sellers with their active buyers

\begin{tabular}{|l|l|l|l|l|}
\hline No & List of vendors & Males & Females & $\begin{array}{l}\text { Number of active } \\
\text { buyers }\end{array}$ \\
\hline 1 & Lazada & 66 & 71 & 137 \\
\hline 2 & Tokopedia & 65 & 75 & 140 \\
\hline 3 & OLX & 89 & 46 & 135 \\
\hline 4 & Bukalapak & 73 & 62 & 135 \\
\hline & Total respondents & & & 547 \\
\hline
\end{tabular}

Table 3: Demographic Data of Respondents

\begin{tabular}{|c|c|}
\hline Variable & Data \\
\hline \multirow{5}{*}{ Age } & $<18$ years old $(\mathrm{Qty}=11->2.0 \%)$ \\
\hline & $18-21$ years old $(\mathrm{Qty}=52->9.5 \%$ \\
\hline & $22-30$ years old (Qty=266 $->48.6 \%)$ \\
\hline & $31-35$ years old (Qty=192 -> 35.1\%) \\
\hline & $>36$ years old $(\mathrm{Qty}=26->4.8 \%)$ \\
\hline \multirow{2}{*}{ Gender } & Male (Qty=293 -> 53.6\%) \\
\hline & Female (Qty=254 -> 46.4\%) \\
\hline \multirow{4}{*}{ Education } & Until High school or equivalent (Qty=92 -> 17.4\%) \\
\hline & Diploma or equivalent (Qty=47 -> 8.6\%) \\
\hline & Undergraduate degree (Qty=369 -> 67.5\%) \\
\hline & Post graduate degree or higher (Qty=36 -> 6.5\%) \\
\hline \multirow{5}{*}{ Domicile } & West Jakarta (Qty=197 -> 36.01\%) \\
\hline & South Jakarta (Qty=91 -> 16.6\%) \\
\hline & Central Jakarta (Qty=70 -> 12.8\%) \\
\hline & North Jakarta (Qty=128 -> 23.4\%) \\
\hline & East Jakarta (Qty=61 -> 11.2\%) \\
\hline
\end{tabular}




\begin{tabular}{|c|c|}
\hline \multicolumn{2}{|c|}{ Table 3: continuation } \\
\hline \multirow{7}{*}{ Occupation } & Student (Qty=58 -> 10.6\%) \\
\hline & Teacher/Lecturer (Qty=4 -> 0.7\%) \\
\hline & Government employees (Qty=20 -> 3.7\%) \\
\hline & Private employees (Qty=317 -> 58\%) \\
\hline & Entrepreneur (Qty=96 -> 17.6\%) \\
\hline & Housewife (Qty=27 -> 4.9\%) \\
\hline & Others (Qty=25 -> 4.6\%) \\
\hline \multirow{6}{*}{$\begin{array}{l}\text { Expenditure per } \\
\text { month outside } \\
\text { installments luxury } \\
\text { goods }\end{array}$} & $<$ USD 100 (Qty=58 -> 10.6\%) \\
\hline & USD 100-200 (Qty=97 -> 17.7\%) \\
\hline & USD 200-300 (Qty=126 ->23.0\%) \\
\hline & USD 300-400 (Qty=107 ->19.6\%) \\
\hline & USD 400-500 (Qty=70 -> 12.8\%) \\
\hline & > USD 500 (Qty=89 ->16.3\%) \\
\hline
\end{tabular}

\subsection{Validity and Reliability Test}

We started to evaluate the normality of data. Normality test was performed by using critical ratio (c.r.) with a range of \pm 2.58 , at a significance level $\alpha=0.01(1 \%)$. We used two tailed tests with the critical value c.r. skewness and kurtosis. After testing for normality, we got some values of coefficient c.r. kurtosis was above 2.58 , so the multivariate normality was not met. To find the cause for non-normality, then we continued with the outlier test. The outlier test was done by using the chi-square statistic (X2) with the Mahalanobis distance squared values at a significance level $\alpha=0.01(1 \%)$. If Mahalanobis distance squared values greater than 46.963 , then the data contained outliers and need to be removed. After removing all outlier data, we confirmed the normality test was passed and data was valid for further analysis.

We continued with Confirmatory Factor Analysis (CFA) method analysis, to test the validity and reliability of indicators conforming with the latent variables. The indicators were all valid with the loading factor $(\lambda)$ more than 0.5 or above [23], and It shows significant impacts. All values of Construct Reliability $(C R)>0.7$ and Cronbach's alpha > 0.6 [32]. The CR and Cronbach's values show all data are ready to use for further analysis. They are shown in table 4 below.

Table 4: Summary validity and reliability test

\begin{tabular}{|c|c|c|c|c|c|}
\hline Variables & Code & $\begin{array}{l}\text { Loding } \\
\text { Factor }\end{array}$ & CR & $\begin{array}{l}\text { Cronbach's } \\
\text { Alpha }\end{array}$ & Status \\
\hline \multirow{3}{*}{$\begin{array}{l}\text { Perceived } \\
\text { Risk }\end{array}$} & PR1 & 0.63 & \multirow[t]{3}{*}{0.8} & \multirow[t]{3}{*}{0.788} & \multirow[t]{3}{*}{ Valid } \\
\hline & PR2 & 0.8 & & & \\
\hline & PR3 & 0.83 & & & \\
\hline \multirow{3}{*}{$\begin{array}{l}\text { Perceived } \\
\text { Usefulness }\end{array}$} & PU1 & 0.75 & \multirow[t]{3}{*}{0.83} & \multirow[t]{3}{*}{0.827} & \multirow[t]{3}{*}{ Valid } \\
\hline & PU2 & 0.87 & & & \\
\hline & PU3 & 0.74 & & & \\
\hline \multirow{3}{*}{$\begin{array}{l}\text { Perceived } \\
\text { Ease of Use }\end{array}$} & PEOU1 & 0.73 & \multirow[t]{3}{*}{0.8} & \multirow[t]{3}{*}{0.798} & \multirow[t]{3}{*}{ Valid } \\
\hline & PEOU2 & 0.77 & & & \\
\hline & PEOU3 & 0.77 & & & \\
\hline \multirow{3}{*}{$\begin{array}{l}\text { E-marketplace } \\
\text { Reputation }\end{array}$} & MR1 & 0.73 & \multirow[t]{3}{*}{0.74} & \multirow[t]{3}{*}{0.741} & \multirow[t]{3}{*}{ Valid } \\
\hline & MR2 & 0.66 & & & \\
\hline & MR3 & 0.71 & & & \\
\hline \multirow{3}{*}{$\begin{array}{l}\text { Seller's } \\
\text { Reputation }\end{array}$} & SR1 & 0.78 & \multirow[t]{3}{*}{0.76} & \multirow[t]{3}{*}{0.821} & \multirow[t]{3}{*}{ Valid } \\
\hline & SR2 & 0.62 & & & \\
\hline & SR3 & 0.74 & & & \\
\hline \multirow{3}{*}{$\begin{array}{l}\text { Seller's } \\
\text { Expertise }\end{array}$} & SE1 & 0.77 & \multirow[t]{3}{*}{0.81} & \multirow[t]{3}{*}{0.811} & \multirow[t]{3}{*}{ Valid } \\
\hline & SE2 & 0.8 & & & \\
\hline & SE3 & 0.74 & & & \\
\hline
\end{tabular}




\begin{tabular}{|c|c|c|c|c|c|}
\hline \multicolumn{6}{|c|}{ Table 4: continuation } \\
\hline \multirow[t]{3}{*}{ Convenience } & CONV1 & 0.77 & \multirow[t]{3}{*}{0,74} & \multirow[t]{3}{*}{0.747} & \multirow[t]{3}{*}{ Valid } \\
\hline & CONV2 & 0.8 & & & \\
\hline & CONV3 & 0.74 & & & \\
\hline \multirow[t]{3}{*}{ Trust } & TRS1 & 0.69 & \multirow[t]{3}{*}{0.77} & \multirow[t]{3}{*}{0.767} & \multirow[t]{3}{*}{ Valid } \\
\hline & TRS2 & 0.72 & & & \\
\hline & TRS3 & 0.73 & & & \\
\hline \multirow[t]{3}{*}{ Satisfaction } & STS1 & 0.73 & \multirow[t]{3}{*}{0.78} & \multirow[t]{3}{*}{0.778} & \multirow[t]{3}{*}{ Valid } \\
\hline & STS2 & 0.67 & & & \\
\hline & STS3 & 0.78 & & & \\
\hline
\end{tabular}

\subsection{The Results of Hypothesis Testing}

The simulation research model with SPSS Amos showed the observed values of Chi-square statistic ( $x 2)$ at 324.442 (good fit: <331,786) and probability (p) at 0.080 (good fit: < 0.05), df at 291 (good fit: positive value), the minimum sample discrepancy function/degree of freedom (CMIN/DF) at 1.119 (good fit: <2.0), Root Mean Square Error of Approximation (RMSEA) at 0.015 (good fit: <0.05), Goodness of fit index (GFI) at, 0.957 (good fit: >0.90). Adjusted Goodness of Fit Index (AGFI) at 0.944 (good fit: >0.90), Tucker Lewis Index (TLI) at 0.993 (good fit: $>0.90$ ), and Comparative Fit Index (CFI at 0.994 (good fit: $>0.90)$. Thus, the research model in this study may be accepted [58]. The result findings were summarized in Table 5 and Figure 2 below:

Table 5: The result of simulation research

\begin{tabular}{|l|l|l|}
\hline$X$ & Chi-square & Good fit \\
\hline$X 2$ & 324.442 & $<331,786$ \\
\hline$p$ & 0.080 & $<0.05$ \\
\hline$d f$ & 291 & positive value \\
\hline CMIN/DF & 1.119 & $<2.0$ \\
\hline RMSEA & 0.015 & $<0.05$ \\
\hline GFI & 0.957 & 0.90 \\
\hline AGFI & 0.944 & $>0.90)$, \\
\hline TLI & 0.993 & $>0.90$ \\
\hline CFI & 0.994 & $>0.90$ \\
\hline
\end{tabular}

Table 6: Results of hypothesis testing

\begin{tabular}{|c|c|c|c|c|c|}
\hline $\mathrm{H}$ & $\begin{array}{l}\text { Standard } \\
\text { Estimate }\end{array}$ & $\begin{array}{l}\text { Standard } \\
\text { Errors }\end{array}$ & C.R. & Prob. & Status \\
\hline $\mathrm{H} 1$ & 0.18 & 0.029 & 4.783 & $\star \star \star *$ & Significant \\
\hline $\mathrm{H} 2$ & 0.162 & 0.031 & 4.026 & 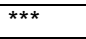 & Significant \\
\hline $\mathrm{H} 3$ & 0.097 & 0.034 & 2.21 & 0.027 & Significant \\
\hline $\mathrm{H} 4$ & 0.374 & 0.053 & 6.418 & $\star \star \star *$ & Significant \\
\hline $\mathrm{H} 5$ & 0.14 & 0.034 & 3.513 & $* * *$ & Significant \\
\hline $\mathrm{H} 6$ & 0.173 & 0.035 & 4.202 & $\star \star \star \star$ & Significant \\
\hline $\mathrm{H} 7$ & 0.242 & 0.047 & 4.925 & $\star \star * *$ & Significant \\
\hline $\mathrm{H} 8$ & 0.089 & 0.035 & 2.109 & 0.035 & Significant \\
\hline $\mathrm{H} 9$ & 0.057 & 0.037 & 1.275 & 0.202 & Not Significant \\
\hline $\mathrm{H} 10$ & 0.118 & 0.041 & 2.56 & 0.01 & Significant \\
\hline $\mathrm{H} 11$ & 0.085 & 0.058 & 1.477 & 0.14 & Not Significant \\
\hline $\mathrm{H} 12$ & 0.777 & 0.097 & 8.393 & $* * *$ & Significant \\
\hline $\mathrm{H} 1$ & 0.18 & 0.029 & 4.783 & $* * *$ & Significant \\
\hline $\mathrm{H} 1$ & 0.162 & 0.031 & 4.026 & *** & Significant \\
\hline $\mathrm{H} 1$ & 0.097 & 0.034 & 2.21 & 0.027 & Significant \\
\hline
\end{tabular}

Note: significant with $\left.\mathrm{p}<0.01, \mathrm{t}>2.58 ;{ }^{* \star \star}\right)$ significant $\mathrm{p}<0.05, \mathrm{t}>1.96$. 


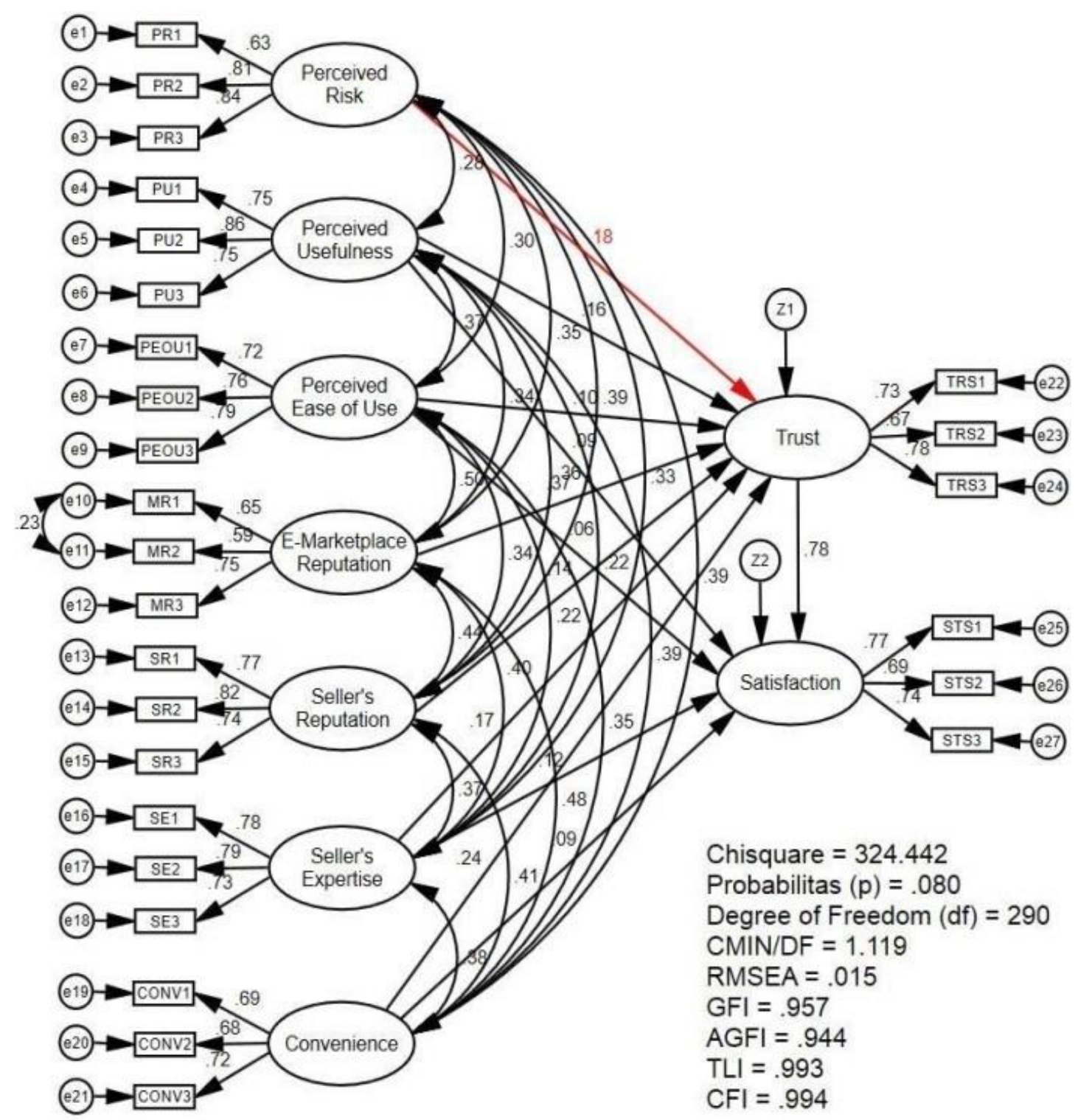

Figure 2: Simulation research model with SPSS amos

Table 6 showed all critical ratio (C.R.) values $>1.96(\alpha=0.01)$ [4], [11] except for H9 and H11. With $p<0.05$ $(\mathrm{t}>1.96)$ the hypotheses $\mathrm{H} 9$ and $\mathrm{H} 11$ were rejected while others are accepted. The overall hypotheses test are summarised in Table 6.

\subsection{Discussion}

The findings above show that: perceived risk, perceived usefulness, perceived ease of use, e-marketplace reputation, seller's reputation, seller's expertise, and convenience show significant effects to increase buyers level of trust $(\mathrm{H} 1-\mathrm{H} 7$ are accepted). It can be understood in low trust society, the trust factor has become the important consideration for the Indonesian buyers to drive the purchasing process. The findings confirms the threat issues in e-marketplace as referred in the McKinsey report [36].

The $\mathrm{H} 8, \mathrm{H} 10$, and $\mathrm{H} 12$, that comprised of: perceived usefulness, e-seller's expertise and trust in online shopping also have a positive effect on buyer satisfaction. It infers the increasing awareness and satisfaction level amongst Indonesian buyers and sellers to the online shopping, especially amongst youngsters [14]. These findings have the impact that more and more Indonesian sellers are transforming their conventional business into online business.

There are interesting findings in $\mathrm{H} 9$ and $\mathrm{H} 11$ that: perceived ease of use and convenience in online shopping did not show significant effects to the buyer satisfaction. These findings also support the survey conducted by Nielsen in 2014 [37] and Shia et.al. [45], where the perceived ease of use and convenience factor have yet 
become the main driver for Indonesian buyers to do online purchase. Indonesian buyers are more driven by the low cost, fast delivery and availability of the product. With large number of increasing middle-class concentrated in big cities [1], [3], supported by high penetration of affordable smartphones [41], better services provided by application-based transportations [59], and government efforts to improve road and internet infrastructure [54], have spurred the rise of online buying behavior [12], [46]. Online buying trend has introduced new solutions to cater high costs economy in product delivery to end user [51]. The trend of online sales has encouraged traditional sellers to embrace new online strategy with creative approaches to acquire as many as possible potential buyers [38].

Based on the finding in the table 6, the hypothesis test is presented in Table 7

Table 7: Summary of hypothesis testing

\begin{tabular}{|l|l|l|}
\hline H & Hypothesis & Status \\
\hline H1 & Perceived risk of online shopping has positive effects on buyer trust & Supported \\
\hline H2 & Perceived usefulness of online shopping has positive effects on buyer trust. & Supported \\
\hline H3 & Perceived ease of use of online shopping has positive effects on buyer trust & Supported \\
\hline H4 & Indonesian e-marketplaces reputation has positive effects on buyer trust. & Supported \\
\hline H5 & e-Seller's reputation has positive effects on buyer trust. & Supported \\
\hline H6 & e-Seller's expertise has positive effects on buyer trust. & Supported \\
\hline H7 & Convenience in online shopping has positive effects on buyer trust. & Supported \\
\hline H8 & Perceived usefulness of online shopping has positive effects on buyer satisfaction. & Supported \\
\hline H9 & Perceived ease of use of online shopping has positive effects on buyer satisfaction. & Not Supported \\
\hline H10 & e-Seller's expertise has positive effects on buyer satisfaction. & Supported \\
\hline H11 & The convenience of online shopping has positive effects on buyer satisfaction. & Not Supported \\
\hline H12 & Trust in online shopping has a positive effect on buyer satisfaction. & Supported \\
\hline
\end{tabular}

The findings above infer the buyers enable to address both internet threat issues and poor image related with online sales. There are other supporting factors accelerate the growth of online sales such as: high penetration of smartphones, increasing middle-income population with majority of ages below 40, developing internet and road infrastructures. These issues become power engine to drive the growth of online sales in Indonesia. The study disclosures new opportunity to understand the Indonesian e-marketplace, where there is very few study can be found to address this issue [29]. The implication of the study infers the Indonesian e-marketplace is attractive place for investment [60], where perceived ease of use and convenience of shopping may not reach satisfactory level yet.

\section{Conclusion}

Latest trends have shown the dramatic increment of internet users in Indonesia. With estimated more than 180 millions and majority inhabitants are dominated by the youngsters, have made Indonesian e-marketplaces one of the most promising business areas in the world. Due to its fast growth in e-marketplaces, however, there are very few articles can be found to analyses the growth of e-marketplaces in Indonesia. For this reason, the article examined the four top sellers in Indonesian e-marketplaces such as Lazada, Tokopedia, OLX, and bukalapak that dominate the Indonesian e-marketplaces. With fast growth of middle-classes with internet exposure, Indonesian sellers and buyers are dealing with new paradigm of doing business where they are not fully aware of doing it. Improving trust and satisfaction factors in Indonesian e-marketplaces are still daunting tasks for all sellers and buyers, where threats and fraudulence can easily be found. The article utilized modified TAM, such as perceived risk, e-market reputation, seller's reputation and expertise, and convenience; and related them to improving trust and convenience of online shopping. The article applied the SEM combined with IBM SPSS Amos Graphics to simulate the findings.

The questionnaires were built on a Likert scale of 5 and were delivered to numerous respondents in the Jakarta area. The Jakarta area was chosen due to major online buyers are conducted in the Jakarta area. The hypotheses were tested and reached the results as expected, except for perceived ease of use (H9) and convenience $(\mathrm{H} 11)$. It can be understood with large number of increasing middle-class concentrated in Jakarta area, supported with high penetration of smartphones, better services provided by application based transportations, and government efforts to improve both roads and internet infrastructures, have spurred the rise of online buyers. E-sellers are competing to reach as many as possible all potential buyers. The factor of low cost, fast delivery and product availability were considered more important rather than ease of use and convenience in buying online. 


\section{Websites List}

Site 1: Lazada.co.id

http://www.lazada.co.id

Site 2: Tokopedia.com

http://www.tokopedia.com

Site 3: Olx.co.id

http://www.olx.co.id

Site 4: Bukalapak.com

http://www.bukalapak.com

\section{References}

[1] M. Ansori, Consumerism and the emergence of a new middle class in globalizing Indonesia, Explorations a Graduate Student Journal of Southeast Asian Studies, vol. 9, 2009.

[2] M. Awais and S. Tanzila, Advanced SWOT analysis of e-commerces, International Journal of Computer Science Issues, vol. 9, no 2, pp. 569-574, 2012.

[3] V. Banerjee and E. Duflo, What is middle class about the middle classes around the world?, The Journal of Economic Perspectives, vol. 22, no. 2, pp. 3-41A, 2008.

[4] M. Byrne, Structural Equation Modeling with AMOS: Basic Concepts, Applications, and Programming. New York: Routledge, 2016.

[5] H. H. Cang and K. H. Wong. Adoption of e-procurement and participation of e-marketplace on firm performance: Trust as a moderator, Information \& Management, vol. 47, no. 5-6, pp. 255-324, 2010.

[6] Y. H. Chen, J. J. Wu, I. R. R. Lu, and S.H. Chien, Exploring impact of e-marketplace reputation and reference group on trust of e-marketplace, in Proceedings PACIS, 2013.

[7] R. Chinomona and M. Sandada, Customer satisfaction, trust and loyalty as predictors of customer intention to re-purchase South African retailing industry, Mediterranean Journal of Social Sciences, vol. 4, no. 14, pp. 437-446, 2013

[8] Y. G. Chien, T. Geraldine, T. Martin, M. Sachin, W. Carol, H. Mavis, S. Andy, T. Derek, Y. Jeff, W. Danielle, S. Mervin, Y. Alfie, T. Rachael, C. Steve, and L. Mark. (2016) E-commerce In Asia. DBS Asian Insights. [Online]. Available: https://www.dbsinsights.com/wp-content/uploads/2016/07/151103 insights e commerce in asia bracing for digital disruption.pdf

[9] K. Choon Ling, D. Bin Daud, T. Hoi Piew, K. H. Keoy, and P. Hassan, Perceived risk, perceived technology, online trust for the online purchase intention in Malaysia, International Journal of Business and Management., vol. 6, no. 6, pp. 167-182, 2011.

[10] K. Christer, The role of trust in B2B electronic commerce: Evidence from two e-marketplaces, Ph.D. dissertation, Division of Industrial Marketing and e-Commerce, Luleå Tekniska Universitet, Suecia, 2005.

[11] U. Dachlan, Panduan Lengkap Structural Equation Modeling Tingkat Dasar. Indonesia: Lentera IImu Jakarta. 2014.

[12] S. Dakduk, E. H. Ter Horst, Z. Santalla, G. Molina, and J. Malave, Customer behavior in electronic commerce: a Bayesian approach, Journal of Theoretical and Applied Electronic Commerce Research, vol. 12, no. 2, pp. 1-20, 2017.

[13] F. D. Davis, User acceptance of information technology: system characteristics, user perceptions and behavioral impacts, International journal of man-machine studies, vol 38, no. 1, pp. 475-487, 1993.

[14] M. F. A. Denmark (2015) Indonesian e-commerce fact sheet. Trade Counc. [Online]. Available: http://um.dk/ /media/UM/Danish-site/Documents/Eksportraadet/Eksportraadet-tilbyder/e-handel/Indonesia eCommerce fact sheet.pdf

[15] M. D. D. Dharmesti and S. S. Nugroho, The antecedents of online customer satisfaction and customer loyalty, Journal of Business and Retail Management Research, vol. 7, no. 2, pp. 1-12, 2013.

[16] H. S. Doong, H. C. Wang and H. C. Shih, Exploring loyalty intention in the electronic marketplace, Electronic Markets, vol. 18, no. 2, pp. 142-149, 2008.

[17] S. P. Ecommerce. (2014) Indonesia's ecommerce landscape 2014: Insights into one of Asia Pacific's fastest growing markets, Singapore post limited. 2014. All rights reserved. Specommerce. [Online]. Available: http://www.specommerce.com.s3.amazonaws.com/dl/wp/141215-white-paper-indonesia.pdf

[18] Q. Fan, J. Yul Lee and J. I. Kim, The impact of web site quality on flow-related online shopping behaviors in C2C e-marketplaces: A cross-national study, Journal of Service Theory and Practice, vol. 23, no. 5, pp. 364-387, 2013.

[19] P. Fouliras, A novel reputation-based model for e-commerce, International journal Operational research, vol. 1, no. 13, pp. 113-138, 2013. 
[20] J. R. Fu, J. H. Chen, The impact of seller expertise and a refund guarantee on auction outcome: Evidence from an online field experiment of camera lens market, International Journal of Electronic Business Management, vol. 9, no. 3, pp. 187-195, 2011.

[21] V. Geril. (2015, February) Buyer-seller relationships across cultures: Conceptual, empirical and methodological issues. Munin Open Research Archive. [Online]. Available: https://munin.uit.no/handle/ $10037 / 7043$

[22] M. E. Greiner and H. Wang, Building consumer-to-consumer trust in e-finance marketplaces: An empirical analysis, International Journal of Electronic Commerce, vol. 15, no. 2, pp. 105-136, 2010.

[23] J. F. Hair, W. C. Black, B. J.Babin, R. E. Anderson, and R. L. Tatham, Multivariate Data Analysis 6th Edition. New Yersey: Pearson Prentice Hall. 2006.

[24] B. Hong and $\mathrm{H}$. Cho, The impact of consumer trust on attitudinal loyalty and purchase intentions in B2C emarketplaces: Intermediary trust vs. seller trust, International Journal of Information Management, vol. 31, no. 5, pp. 469-479, 2011

[25] H. Jiao, J. Liu, J. Li, and C. Liu, A paradox for trust and reputation in the e-commerce world, in Proceedings of the Thirty-Sixth Australasian Computer Science Conference, Australia, 2013, pp. 69-78.

[26] T. Jiradilok, S. Malisuwan, N. Madan, and J. Sivaraks, The impact of customer satisfaction on online purchasing: A case study analysis in Thailand, Journal of Economics, Business and Management, vol. 2, no. 1, pp. 5-11, 2014

[27] J G. Jolivet, B. Jullien and F. P. Vinay, Reputation and prices on the e-market: Evidence from a major french platform, International Journal of Industrial Organization. vol. 31, no. 45, pp. 59-75, 2016.

[28] J. Joo, Roles of the buyer's trust in seller in posted-price model of consumer to consumer e-commerce, Journal of Theoretical and Applied Electronic Commerce Research, vol. 10, no. 3, pp.30-44, 2015.

[29] M. Kartiwi, Case studies of e-commerce adoption in Indonesian SMEs: The evaluation of strategic use, Australasian Journal of Information Systems, vol. 14, no. 1, pp. 69-80, 2006.

[30] M. S. Kim and J. H. Ahn, Comparison of trust sources of an online market-maker in the e-marketplace: Buyer's and seller's perspectives, Journal of Computer Information Systems, vol. 47, no. 1, pp. 84-94, 2006.

[31] M. S. Kim and J. H. Ahn, Management of trust in the e-marketplace: The role of the buyer's experience in building trust, Journal of Information Technology, vol. 22, no. 2, pp. 119-132, 2007.

[32] P. Kline, The Handbook of Psychological Testing. New York: Routlege, 2013.

[33] N. Leonard, Attitude influencers in C2C e-commerce: Buying and selling, Journal of Computer Information Systems, vol. 1, no. 52, pp. 11-7, 2012.

[34] X. Liu, M. He, F. Gao, and P. Xie, An empirical study of online shopping customer satisfaction in China: A holistic perspective, International Journal of Retail \& Distribution Management, vol. 36, no. 11, pp. 919-940, 2008.

[35] H. Mavis, A. SIM, L. Mark, Y. Alfie, and C. Steve. (2015, April) Asia retail sector. DBS. [Online]. Available: https://www.dbs.com.sg/treasures/aics/pdfController.page?pdfpath=/content/article/pdf/AIO/150430 insights diaital disruption to asia retail sector.pdf

[36] McKinsey. (2015) Global media report 2015. Global Industry Overview, 2015. [Online]. Available: https://www.mckinsey.com/ /media/McKinsey/dotcom/client service/Media\%20and\%20Entertainment/PDF s/McKinsey\%20Global\%20Report\%202015 UK October 2015.ashx

[37] A. Nielsen. (2016, February) Global e-commerce \& the new retail report Q3 2014 - Singapore data. Shopnielsen. [Online]. Available: http://www.shopnielsen.com/reports/global-e-commerce-the-new-retailreport-q3-2014-singapore-data

[38] R. P. Nirmala and I. J. Dewi, The effects of shopping orientations, consumer innovativeness, purchase experience, and gender on intention to shop for fashion products online, Gadjah Mada International Journal of Business, vol. 13, no. 1, pp. 65-83, 2011

[39] R. Oberman, R. Dobbs, A. Budiman, F. Thompson, and M. Rosse, The Archipelago Economy: Unleashing Indonesia's Potential. Jakarta: McKinsey Global Institute, 2012.

[40] W.C. Price. (2016) Indonesian infrastructure stable foundations for growth, the second edition of PwC's annual Indonesian infrastructure report. PWC. [Online]. Available: https://www.pwc.com/id/en/cpi/asset /indonesian-infrastructure-stable-foundations-for-growth.pdf

[41] L. Puspitasari and K. Ishii, Digital divides and mobile Internet in Indonesia: Impact of smartphones, Telemat Informatics, vol. 33, no. 2, pp. 472-83, 2016.

[42] S. A. Pratminingsih, C. Lipuringtyas and T. Rimenta, Factors influencing customer loyalty toward online shopping, International Journal of Trade, Economics and Finance, vol. 4, no. 3, pp. 104-110, 2013.

[43] S. Rahman and A. Z. Zainal, Service quality and students' satisfaction towards purchasing online educational resources, Journal of Marketing Management, vol. 2, no. 2, pp. 57-64, 2014.

[44] A. Safari, Customers' international online trust-insights from focus group interviews, Journal of Theoretical and Applied Electronic Commerce Research, vol. 7, no 2, pp. 59-72, 2012.

[45] C. Shia, M. Chen, A. D. Ramdansyah, and S. Wang, Comparison of decision making in adopting ecommerce between Indonesia and Chinese Taipei (case study in Jakarta and Taipei City), American Journal of Industrial and Business Management, vol 5, no. 12, pp. 748-768, 2015.

[46] W. L. Shiau and M. M. Luo, Factors affecting online group buying intention and satisfaction: A social exchange theory perspective, Computers in Human Behavior, vol. 28, no. 6, pp. 2431-2444, 2012.

[47] T. J. Smith and R. Spiers, Perceptions of e-commerce Web sites across two generations, Informing Science: The International Journal of an Emerging Transdiscipline, vol. 12, pp. 159-180, 2009. 
[48] M. Suresh and R. Shashikala, Identifying factors of consumer perceived risk towards online shopping in India, in Proceedings 3rd International Conference on Information and Financial Engineering IPEDR 2011, IACSIT Press, Singapore, 2011, pp. 336-341.

[49] T. A. Suter and D. M. Hardesty, Maximizing earnings and price fairness perceptions in online consumer-toconsumer auctions, Journal of Retailing, vol. 81, no. 4, pp. 307-317, 2015.

[50] K. Swapna, The design and implementation of an e-commerce site for online book sales, PhD. dissertation, Department of Computer and Information Sciences, Indiana University, South Bend, 2007.

[51] R. Tiwari and C. Herstatt, Assessing India's lead market potential for cost-effective innovations, Journal of Indian Business Research, vol. 4, no. 2, pp. 97-115, 2012.

[52] C. C. Tu, K. Fang and C. Y. Lin, Perceived ease of use, trust, and satisfaction as determinants of loyalty in e-auction marketplace, Journal of Computer, vol. 7, no. 3, pp. 645-652, 2012.

[53] J. A. Wagner, N. M. Klein and J. E. Keith, Buyer-seller relationships and selling effectiveness: The moderating influence of buyer expertise and product competitive position, Journal of Business Research, vol. 56, no. 4, pp. 295-302, 2003.

[54] F. Wahid, Using the technology adoption model to analyze internet adoption and use among men and women in Indonesia, The Electronic Journal of Information Systems in Developing Countries, vol. 32, no. 6, pp. 1-8, 2007.

[55] W. W. Wan, C. L. Luk, K. S. Fam, P. Wu, and C. W. Chow, Interpersonal relationship, service quality, seller expertise: How important are they to adolescent consumers?. Psychology \& Marketing, vol. 29, no. 5, pp. 365-377, 2012.

[56] K. Wei, Y. Zha and H. Sun, Exploring the impact of trust and relational embeddedness in e-marketplaces: An empirical study in Taiwan, Industrial Marketing Management, vol. 41 no. 3, pp: 460-468, 2012.

[57] K. Wei, Y. Zha and H. Sun, A comparative study of buyers' and sellers' transaction intentions in consumerto-consumer e-marketplaces, in Proceedings, PACIS, 2014.

[58] J. C. Westland, Structural equation models, Stud. Syst. Decis. Control, vol. 22, no. 5, p. 152, 2015

[59] F. A. W. Wirawan and E. Oktivera, Analysis on the implementation of digital marketing towards motorbike transport service case study: GO-JEK (online taxi motorbike) Jakarta, Indonesia, in Proceedings International Conference Information Technology Systems and Innovation (ICITSI), Indonesia, 2015. pp. 1-6.

[60] J. Xu and M. Quaddus, E-Business in the 21st Century: Realities, Challenges and Outlook, vol. 2. Australia: World Scientific, 2010. 


\section{Appendix A: Questionnaire}

\section{Assessing the Buyer Trust and Satisfaction Factors in the E-Marketplaces}

Dear Value Respondents,

We would like to ask your favour to fill in the following profile and questionnaire. We highly appreciate your opinion to this questionnaire.

Thank you very much for your kind cooperation.

Regards,

\section{Input your Profile:}

Please circle the following option to illustrate your profile:

\begin{tabular}{|c|c|c|}
\hline \multirow{3}{*}{ Age } & 1. $<18$ years old & 2. $18-21$ years old \\
\hline & 3. 22-30 years old & 4. 31-35 years old \\
\hline & 5. $>=36$ years old & \\
\hline Gender & 1. Male & 2. Female \\
\hline \multirow{2}{*}{ Education } & 1. Until High school or equivalent & 2. Diploma or equivalent \\
\hline & 3. Undergraduate degree & 4. Post graduate degree or higher \\
\hline \multirow{3}{*}{ Domicile } & 1. West Jakarta & 2. South Jakarta \\
\hline & 3. Central Jakarta & 4. North Jakarta \\
\hline & 5. East Jakarta & \\
\hline \multirow{4}{*}{ Occupation } & 1. Student & 2. Teacher/Lecturer \\
\hline & 3. Government employees & 4. Private employees \\
\hline & 5. Entrepreneur & 6. Housewife \\
\hline & 7. Others & \\
\hline \multirow{3}{*}{$\begin{array}{l}\text { Expenditure per } \\
\text { month outside } \\
\text { installments } \\
\text { luxury goods }\end{array}$} & 1. $<$ USD 100 & 2. USD 100-200 \\
\hline & 3. USD 200-300 & 4. USD $300-400$ \\
\hline & 5. USD $400-500$ & 6. > USD 500 \\
\hline
\end{tabular}

\section{QUESTIONNAIRE}

Please circle the following option to express your opinion:

Example:

The following statement shows your opinion to the role of management support in the organisation.

\begin{tabular}{|l|l|l|l|l|l|}
\hline Indicator & $\begin{array}{l}\text { Not } \\
\text { Relevant }\end{array}$ & $\begin{array}{l}\text { Some what } \\
\text { Relevant }\end{array}$ & $\begin{array}{l}\text { Quite } \\
\text { Relevant }\end{array}$ & Relevant & $\begin{array}{l}\text { Highly } \\
\text { Relevant }\end{array}$ \\
\hline $\begin{array}{l}\text { Organisation should provide } \\
\text { effective communication line for the } \\
\text { internal staffs. }\end{array}$ & 1 & 2 & 3 & 4 & 5 \\
\hline
\end{tabular}

A. This statement illustrates the assessment of buyer trust and satisfaction to the perceived risk of emarketplaces (PR).

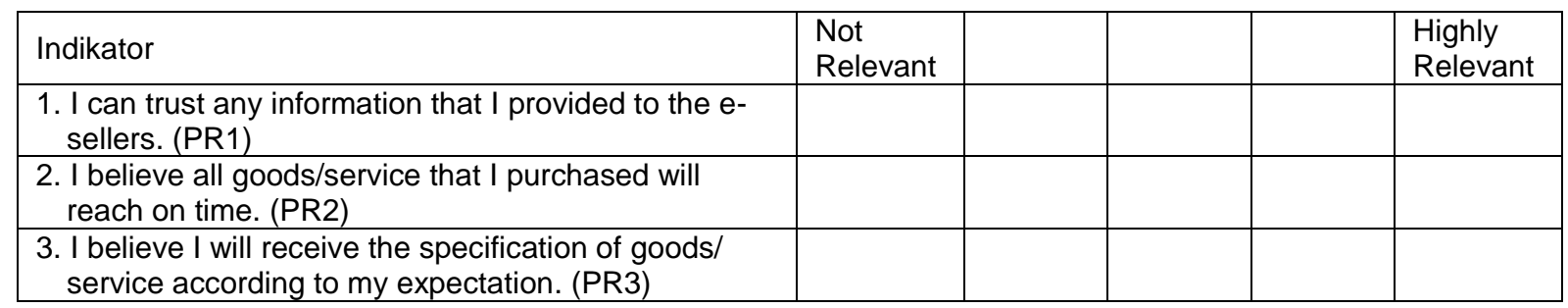


B. The following statement illustrates the assessment of buyer trust and satisfaction to perceived usefulness of e-marketplaces (PU).

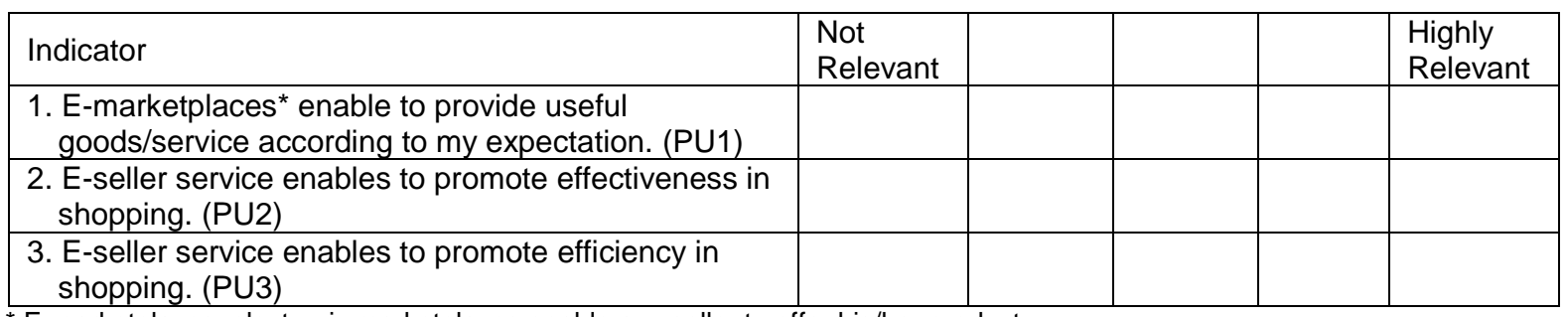

${ }^{*}$ E-marketplaces: electronic marketplaces enable any seller to offer his/her product.

C. The following statement illustrates the assessment of buyer trust and satisfaction to perceived ease of use of e-marketplaces (PEOU).

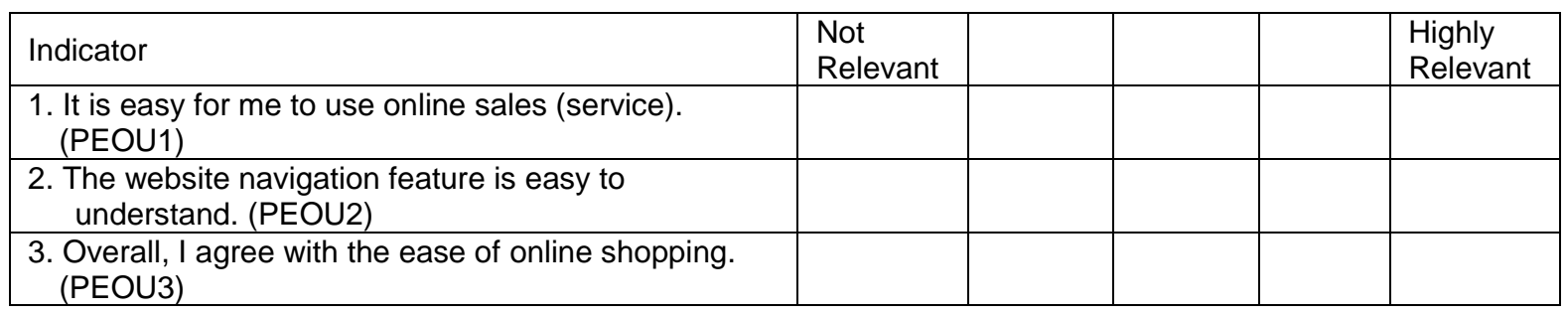

D. The following statement illustrates the assessment of buyer trust and satisfaction to e-marketplace reputation (MR).

\begin{tabular}{|l|l|l|l|l|l|}
\hline Indicator & $\begin{array}{l}\text { Not } \\
\text { Relevant }\end{array}$ & & & & $\begin{array}{l}\text { Highly } \\
\text { Relevant }\end{array}$ \\
\hline $\begin{array}{l}\text { 1. Nowadays, people realise online shopping is quite } \\
\text { popular. (MR1) }\end{array}$ & & & & & \\
\hline 2. I am familiar with e-sellers. (MR2) & & & & & \\
\hline 3. E-sellers develop good reputation. (MR3) & & & & & \\
\hline
\end{tabular}

E. The following statement illustrates the assessment of buyer trust and satisfaction to e-seller's reputation (SR).

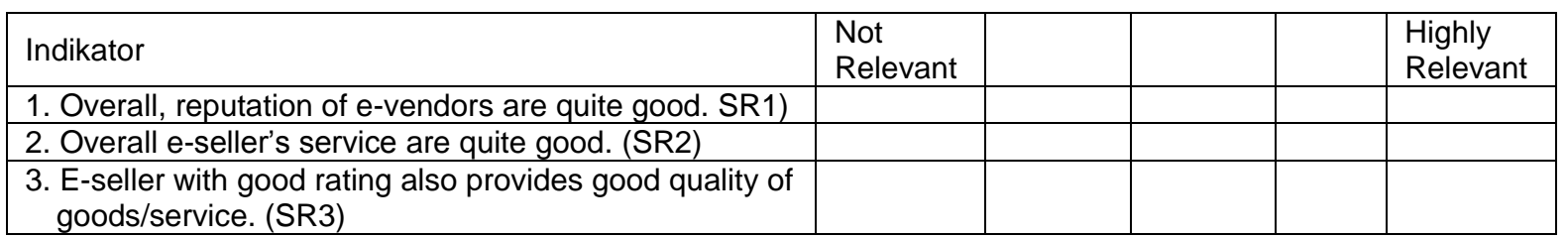

F. The following statement illustrates the assessment of buyer trust and satisfaction to e-seller's expertise (SE).

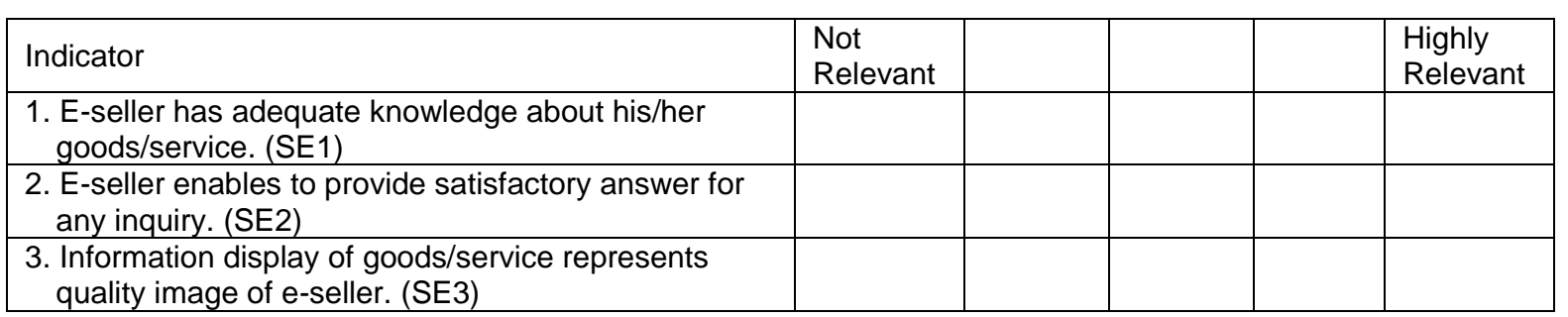

G. The following statement illustrates the assessment of buyer trust and satisfaction to e-marketplace convenience (CONV).

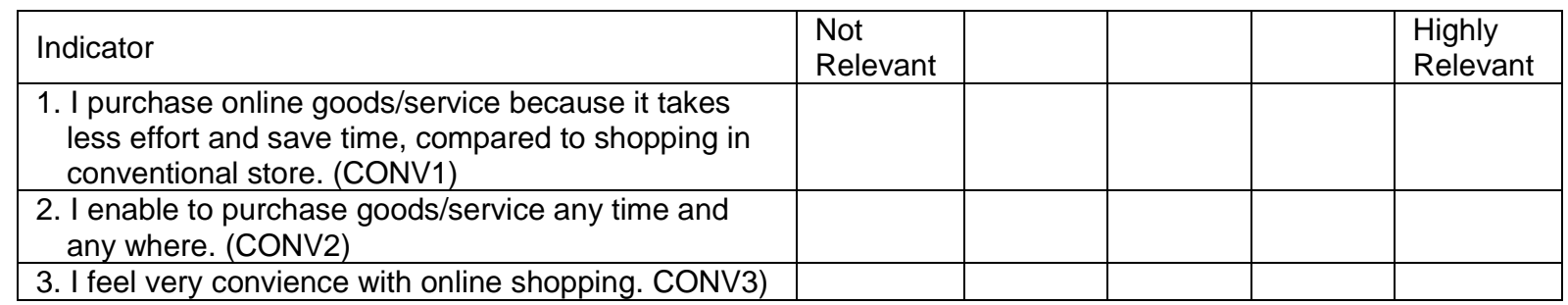


$\mathrm{H}$. The following statement illustrates the assessment of buyer trust and satisfaction to e-marketplace trust (TRS).

\begin{tabular}{|c|c|c|}
\hline Indicator & $\begin{array}{l}\text { Not } \\
\text { Relevant }\end{array}$ & $\begin{array}{l}\text { Highly } \\
\text { Relevant }\end{array}$ \\
\hline 1. I trust e-sellers in marketplace. (TRS1) & & \\
\hline 2. I trust commitment offered by e-seller. (TRS2) & & \\
\hline 3. I trust payment system offered by e-seller. (TRS3) & & \\
\hline
\end{tabular}

I. The following statement illustrates the assessment of buyer trust and satisfaction of e-marketplace (STS).

\begin{tabular}{|l|l|l|l|l|}
\hline Indikator & $\begin{array}{l}\text { Not } \\
\text { Relevant }\end{array}$ & & & $\begin{array}{l}\text { Highly } \\
\text { Relevant }\end{array}$ \\
\hline $\begin{array}{l}\text { 1. Overall, I am quite satisfied with my experience dealing } \\
\text { with e-sellers. (STS1) }\end{array}$ & & & & \\
\hline $\begin{array}{l}\text { 2. I have good impression with the service provided by e- } \\
\text { sellers. (STS2) }\end{array}$ & & & & \\
\hline $\begin{array}{l}\text { 3. The performance of e-sellers suit to my expectation. } \\
\text { (STS3) }\end{array}$ & & & & \\
\hline
\end{tabular}

